\title{
Relationship among body condition, subcutaneous fat and production performance of Jersey crossbred cows
}

\author{
ABHISHEK PAUL ${ }^{1}$, CHAMPAK BHAKAT $^{2}$, DK MANDAL $^{3}$, A MANDAL $^{4}$, A MOHAMMAD $^{5}$, A CHATTERJEE $^{6}$ \\ and T K DUTTA ${ }^{7}$
}

Eastern Regional Station, ICAR-National Dairy Research Institute, Kalyani, West Bengal 741235 India

Received: 5 July 2018; Accepted: 29 October 2018

Key words: Body condition, Body weight, Jersey crossbred, Milk production, Ramp fat thickness

Important ability of milking cow is their capacity of using body energy stores during periods of negative energy balance in order to supply their basal metabolism, lactation and reproduction. The reproductive performance of animals is extremely important for dairy industry (Talokar et al. 2018). Evaluation of BCS and body weight (BW), rump fat thickness (RFT/BFT) can be used to estimate body energy reserves of animals (Schroder and Staufenbiel 2006). To get higher milk production along with restoration of body condition, present study was conducted to determine relationship between BCS, RFT/BFT, body measurements, body weight, and milk production of Jersey crossbred cows reared at organized farm.

The study was carried out at an organized cattle farm of the institute. A total of 44 Jersey crossbred cows were taken for this experiment from calving to 120 days post-partum. Based on body condition score (BCS) at calving animals were grouped into 3 different classes, i.e. low (9), medium (23) and high (12) BCS group. However, cows were free from all kind of physiological, anatomical and infectious disorders. Feeding and other managements were similar for all the groups. BCS of animals were assigned using visual plus palpation technique according to the guidelines established by Prasad and Tomar (1994) at fortnight interval. For assessing body condition of animals, anatomical regions (critical points) were taken into account meticulously.

With the advent of ultra-sonography, back/ramp fat thickness (BFT/RFT) can be objectively measured and used to assess energy status of dairy cows in conjunction with BCS throughout experimental period at fortnight interval. BFT/RFT was determined after morning milking by using ultrasonography machine (Mindray, Model-DP6600vet). The USG images were taken in B-mode, using $5 \mathrm{MHz}$ frequency with a linear transducer. Everyday milk

Present address: 2Principal Scientist (bhakat56@gmail.com), ${ }^{1} \mathrm{PhD}$ Scholar (abhishek2011v01@gmail.com), Livestock Production and Management Section; ${ }^{4}$ Principal Scientist (ajoymondal@gmail.com), Animal Breeding Section; ${ }^{5}$ Scientist (mail.asif.m@ gmail.com), Extension section; ${ }^{7}$ Principal Scientist (tkdcirg@gmail.com), Animal Nutrition Section. productions were recorded twice. The morning and evening yield was added to consider per day production and every fortnight interval average was taken for all experimental animals. The body weight (BW) of experimental animals was recorded initially at calving and subsequently at 15 days interval. Body weight of each animals were measured in the morning between 8.30 AM to 9.30 AM after completing morning milking and before providing any feed or water, using an electronic weighing scale with a precision of $200 \mathrm{~g}$. Body measurements were recorded on the same day of recording of BCS, body weight, BFT. Tail head thickness (THT) was measured by using a vernier calipers. Heart girth (HG), and abdominal girth (AG) were measured by using a measuring tape. Data were analysed by using the multivariate general linear model method for analysis of variance followed by mean comparisons for all pairs using Tukey-Kramer HSD test. The correlation coefficients were determined as per Pearson correlation (Snedecor and Cochran 1994).

Analyzed data of BCS (Table 1) revealed that there was a nonsignificant variation of BCS among 3 groups at calving (0 day) which continued up to 30 days after calving. The significant $(\mathrm{P}<0.05)$ variations of $\mathrm{BCS}$ among 3 groups were observed after 45 days of calving. The body condition of cows were significantly less in group 1 than group 2 and group 3. The overall BCS varied significantly $(\mathrm{P}<0.05)$ among 3 groups. The group 3, lost BCS faster than other 2 groups from calving to 120 days. The comparison of overall means revealed significant differences among 3 BCS groups because more metabolic energy is spent in milk production by high BCS group. Higher BCS group lost more body condition followed by medium and low BCS group, at early lactation stage. Similar type of finding was reported by Roche et al. (2007). The mean HG, THT, AG (cm) of Jersey crossbred cows at calving (0 day) were similar (Table 2) but after 120 days of calving all these parameters were significantly $(\mathrm{P}<0.05)$ higher in group 3 followed by group 2 and group 1. A linear relationship was between BCS and body measurement parameters. The variation in THT might be due to increase in amount of fat reserve in body tissue of tail head. The significant variation at 120 days of calving 
Table. 1 Least-squares (Mean \pm SE) of body condition score in Jersey crossbred lactating cows

\begin{tabular}{|c|c|c|c|c|}
\hline $\begin{array}{l}\text { Period after } \\
\text { calving }\end{array}$ & $\begin{array}{c}\text { Group } 1 \\
\text { (Low BCS) }\end{array}$ & Groups 2 & $\begin{array}{c}\text { Groups } 3 \\
\text { (High BCS) }\end{array}$ & Overall \\
\hline$d$ & $2.11^{\mathrm{a}}$ & 9 & 5.5 & 3.91 \\
\hline 5 dav & $1.89^{\mathrm{a}}$ & & & \\
\hline 0 days & 1.61 & 3.6 & 4.7 & $3.36 \pm 0.09$ \\
\hline 45 days & $1.61^{\mathrm{a}} \pm 0$. & $3.52^{\mathrm{b}} \pm 0$ & $4.79^{c} \pm 0$ & 3.31 \\
\hline da & $1.72^{\mathrm{a}} \pm 0$ & $3.52^{\mathrm{b}} \pm 0$ & & .09 \\
\hline & & & 4.2 & .12 \\
\hline 90 days & $1.89^{\mathrm{a}} \pm 0.29$ & $3.48^{\mathrm{b}} \pm 0.18$ & \pm 0.25 & $3.16 \pm 0.14$ \\
\hline 105 days & $1.89^{\mathrm{a}} \pm 0.32$ & $3.48^{\mathrm{b}} \pm 0.20$ & $4.17^{c} \pm 0.28$ & $3.18 \pm 0.16$ \\
\hline 120 days & $1.83^{\mathrm{a}} \pm 0.33$ & $3.54^{\mathrm{b}} \pm 0.21$ & $4.33^{\mathrm{c}} \pm 0.29$ & $3.24 \pm 0.16$ \\
\hline Overall & $1.80^{\mathrm{a}} \pm 0.08$ & $3.62^{\mathrm{b}} \pm 0.05$ & $4.61^{c} \pm 0.07$ & \\
\hline
\end{tabular}

Means with different superscripts differ significantly $(\mathrm{P}<0.05)$ from each other

Table 2. Least-square (Mean \pm SE) of body measurement in Jersey crossbred cows under different BCS group

\begin{tabular}{|c|c|c|c|c|c|}
\hline $\begin{array}{l}\text { Parameter } \\
\text { (in } \mathrm{cm} \text { ) }\end{array}$ & Period & $\begin{array}{l}\text { Group } 1 \\
\text { (Low } \\
\text { BCS) }\end{array}$ & $\begin{array}{c}\text { Group } 2 \\
\text { (Medium } \\
\text { BCS) }\end{array}$ & $\begin{array}{c}\text { Group } 3 \\
\text { (High } \\
\text { BCS) }\end{array}$ & Overall \\
\hline $\begin{array}{l}\text { Heart } \\
\quad \text { girth }(\mathrm{HG})\end{array}$ & $\begin{array}{c}0 \text { day } \\
120 \\
\text { days }\end{array}$ & $\begin{array}{c}180.22^{\mathrm{a}_{ \pm}} \\
0.98 \\
168.55^{\mathrm{a}_{ \pm}} \\
0.64\end{array}$ & $\begin{array}{c}182.65^{\mathrm{a}_{ \pm}} \\
0.83 \\
169.00^{\mathrm{b}} \pm \\
0.90\end{array}$ & $\begin{array}{c}168.17^{\mathrm{a}_{ \pm}} \\
0.92 \\
172.33^{\mathrm{c}} \pm \\
0.94\end{array}$ & $\begin{array}{c}178.00 \pm \\
0.82\end{array}$ \\
\hline $\begin{array}{l}\text { Tail head } \\
\text { thickness } \\
\text { (THT) }\end{array}$ & $\begin{array}{c}0 \\
\text { day } \\
120 \\
\text { days }\end{array}$ & $\begin{array}{c}28.22^{\mathrm{a}_{ \pm}} \\
0.85 \\
12.33^{\mathrm{a}_{ \pm}} \\
0.12\end{array}$ & $\begin{array}{c}31.22^{\mathrm{a}} \pm \\
0.97 \\
12.30^{\mathrm{b}} \pm \\
0.15\end{array}$ & $\begin{array}{c}33.34^{\mathrm{a}_{ \pm}} \\
0.86 \\
12.17^{\mathrm{c}_{ \pm}} \\
0.15\end{array}$ & $\begin{array}{l}23.5 \pm \\
0.13\end{array}$ \\
\hline $\begin{array}{l}\text { Abdominal } \\
\text { girth (AG) }\end{array}$ & $\begin{array}{c}0 \\
\text { day } \\
120 \\
\text { days }\end{array}$ & $\begin{array}{c}209.33^{\mathrm{a}_{ \pm}} \\
2.64 \\
203.56^{\mathrm{a}} \pm \\
1.59\end{array}$ & $\begin{array}{c}215.78^{\mathrm{a}_{ \pm}} \\
2.94 \\
209.09^{\mathrm{b}} \pm \\
2.07\end{array}$ & $\begin{array}{c}215.42^{\mathrm{a}_{ \pm}} \\
2.78 \\
211.08^{\mathrm{c}_{ \pm}} \\
2.26 .5\end{array}$ & $\begin{array}{c}211.00 \pm \\
1.96\end{array}$ \\
\hline
\end{tabular}

Means with different superscripts differ significantly $(\mathrm{P}<0.05)$ from each other.

might be due to increase in the size of the animal. Gallao $e t$ al. (2001), strong correlation between HG and BCS. In this study, USG images of RFT were immediately analyzed as soon as they were recorded. Comparison of group means showed that BFT/RFT varied nonsignificantly among 3 groups (Table 3 ) at calving but after 15 days of calving RFT was significant $(\mathrm{P}<0.05)$ among 3 groups. However, more back fat thickness was found in high BCS group followed by medium and low BCS group. The faster mobilization of RFT was assessed in group 3 followed by group 2 and group 1. The BFT can be reflected as subcutaneous fat layer located between skin and fascia trunci profunda above gluteus medium and biceps femuris muscles. A linear relationship was found between BCS and BFT/RFT. Hussein et al. (2013) found that there was correlation between BFT and BCS. The variation found could be due to lipolysis of body fat reserve during early lactation which affects BCS of dairy cattle. Fat mobilization was more in high BCS group. In this study, the use of BFT
Table 3. Least-squares (Mean \pm SE) of ramp/back fat thickness (BFT/RFT) under different periods and BCS group

\begin{tabular}{lcccc}
\hline $\begin{array}{l}\text { Periods after Group 1 } \\
\text { calving }\end{array}$ & $\begin{array}{c}\text { Group 2 } \\
(\text { Low BCS })\end{array}$ & $\begin{array}{c}\text { Group 3 } \\
\text { Medium BCS })\end{array}$ & Overall \\
\hline 0 day & $8.77^{\mathrm{a}} \pm 1.54$ & $20.20^{\mathrm{a}} \pm 0.91$ & $30.71^{\mathrm{a}} \pm 1.25$ & $19.89 \pm 1.23$ \\
15 days & $8.16^{\mathrm{a}} \pm 1.52$ & $19.13^{\mathrm{b}} \pm 0.90$ & $27.85^{\mathrm{c}} \pm 1.24$ & $18.38 \pm 1.22$ \\
30 days & $7.80^{\mathrm{a}} \pm 1.53$ & $18.28^{\mathrm{b}} \pm 0.90$ & $26.52^{\mathrm{c}} \pm 1.25$ & $17.53 \pm 1.22$ \\
45 days & $7.15^{\mathrm{a}} \pm 1.61$ & $17.41^{\mathrm{b}} \pm 0.95$ & $25.70^{\mathrm{c}} \pm 1.32$ & $16.75 \pm 1.29$ \\
60 days & $7.31^{\mathrm{a}} \pm 1.60$ & $16.59^{\mathrm{b}} \pm 0.94$ & $24.93^{\mathrm{c}} \pm 1.30$ & $16.27 \pm 1.28$ \\
75 days & $7.38^{\mathrm{a}} \pm 1.69$ & $16.00^{\mathrm{b}} \pm 0.10$ & $23.96^{\mathrm{c}} \pm 1.37$ & $15.78 \pm 1.05$ \\
90 days & $7.68^{\mathrm{a}} \pm 1.75$ & $15.48^{\mathrm{b}} \pm 1.03$ & $23.38^{\mathrm{c}} \pm 1.43$ & $15.51 \pm 1.40$ \\
105 days & $7.96^{\mathrm{a}} \pm 1.85$ & $15.13^{\mathrm{b}} \pm 1.09$ & $23.06^{\mathrm{c}} \pm 1.51$ & $15.38 \pm 1.48$ \\
120 days & $8.04^{\mathrm{a}} \pm 2.00$ & $14.88^{\mathrm{b}} \pm 1.18$ & $23.30^{\mathrm{c}} \pm 1.64$ & $15.40 \pm 1.60$ \\
Overall & $7.80^{\mathrm{a}} \pm 0.58$ & $17.00^{\mathrm{b}} \pm 0.34$ & $25.38^{\mathrm{c}} \pm 0.48$ & \\
\hline
\end{tabular}

Means with different superscripts differ significantly $(\mathrm{P}<0.05)$ from each other.

was chosen based on various reasons. The rump is an area of easy assessment and this is the site of examination to evaluate animal BCS. Subcutaneous fat thickness measurement at rump site demonstrated that it could be used with same efficiency as fat thickness measured between the $12^{\text {th }}$ and $13^{\text {th }}$ ribs (UFAT). This indicates possibility of using RFT as an alternative to UFAT. Another advantage is simplicity of performing this measurement, both for easy assessment of this site (rump) and because any trained operator is able to execute it with higher precision, agility and repeatability when compared to UFAT. In this study, a high correlation between BCS and BFT, and $\mathrm{BCS}$ and $\mathrm{BW}$ were observed. Even with great amplitude of BCS values a high correlation between BCS and RFT was detected. These results reinforce the idea that BCS can be used to predict BFT at any moment. Analysis of correlation coefficients revealed that BCS had strong and significant $(\mathrm{P}<0.01)$ correlation with $\mathrm{BFT} / \mathrm{RFT}$ and body weight of animal. While BCS had low and nonsignificant correlation with milk production of Jersey crossbred cows. BCS had medium and significant $(\mathrm{P}<0.01)$ correlation with AG whereas low but significant $(\mathrm{P}<0.01)$ correlation with HG and THT. RFT/BFT showed medium and significant $(\mathrm{P}<0.01)$ correlation with body weight but low and significant $(\mathrm{P}<0.01)$ correlation with milk yield whereas medium and significant $(\mathrm{P}<0.01)$ correlation with $\mathrm{HG}$, THT, AG over the time. The BW was lowly but significantly $(\mathrm{P}<0.01)$ correlated with milk production, HG, THT, AG from calving to 120 days. All correlation coefficients were positively correlated to each other. Analyzed data of milk production revealed that there was a nonsignificant variation of milk yield among 3 groups. A linear relationship was found between BCS and milk yield. Group 3, lost BCS and BFT faster than other two groups. Higher BCS group lost more body condition along with faster mobilization of RFT at early lactation stage than medium and low BCS group to support milk production. Berry et al. (2007) found 5\% level significance among BCS and daily milk yield. However, more milk yield was observed in high BCS group followed by medium and low BCS group in that order. Contrary to 
this finding, Roche et al. (2007) reported higher milk production in cows having moderate BCS. The comparison of mean between groups revealed that body weight of cows were significantly $(\mathrm{P}<0.05)$ less in group 1 than group 2 and group 3 after 60 days of calving. The similar trends of results were found up to 120 days of calving. The body condition of cows under high BCS were more as compared to medium BCS group. The overall BW significantly $(\mathrm{P}<0.05)$ varied among 3 groups. The high $\mathrm{BCS}$ group, lost $\mathrm{BW}$ faster than other 2 groups. This is because more metabolic energy is spent in milk production by high BCS group. Higher BCS group lost body weight at faster rate than medium and low BCS group during early lactation stage. A linear relationship was detected between BCS and BW. Lake et al. (2006) found that body weight of high BCS group tends to decrease rapidly as compared to medium and low BCS group of animals at $0-15$ days post partum. The variation found might be due to more fat reserves in body tissues of animal at calving. It can be concluded that BCS at calving can be used as a reliable criterion in choosing Jersey crossbred cows for higher milk production at organized farm.

\section{SUMMARY}

To determine relationship between BCS, ramp fat thickness, body measurements and milk yield, a total of 44 Jersey crossbred cows were observed from calving to 120 days post-partum. The ultrasonography images were recorded from rump region during entire experimental period. Statistically analyzed data revealed that BCS, HG, THT were significantly $(\mathrm{P}<0.05)$ less in group 1 than group 2 and group 3. RFT/BFT differences were significant $(\mathrm{P}<0.05)$ among 3 groups. More RFT was found in high BCS group followed by medium and low BCS group. The $B C S$ was having strong and significant $(\mathrm{P}<0.01)$ correlation with RFT and body weight of animals. The RFT was significantly $(\mathrm{P}<0.01)$ correlated with body weight, milk yield, HG, THT and AG. The higher BCS group, lost RFT, BCS and BW faster than other 2 groups to support milk production. It can be concluded that BCS at calving can be used as a reliable criterion in choosing Jersey crossbred cows for higher milk production at organized farm.

\section{ACKNOWLEDGEMENTS}

Authors are thankful to Director, NDRI and also to WBUAFS (Department of Physiology) who provided USG machine during experimentation.

\section{REFERENCES}

Berry D P, Macdonald K A, Stafford K, Matthews L and Roche J R. 2007. Associations between body condition score, body weight and somatic cell count and clinical mastitis in seasonally calving dairy cattle. Journal of Dairy Science 90: 637-48.

Gallao L, Carnier P, Cassandro M, Dal Zotto R and Bittante G. 2001. Test day genetic analysis of condition score and heart girth in Holstein Friesian cows. Journal of Dairy Science 84: 2321-26.

Hussein H A, Westphal A and Staufenbiel R. 2013. Relationship between body condition score and ultrasound measurement of back fat thickess in multiparous Holstein dairy cows at different production phases. Australian Veterinary Journal 91: 185-89.

Lake S L, Scholljegerdes E J, Hallford D M, Moss G E, Rule D C and Hess B W. 2006. Effects of body condition score at parturition and postpartum supplemental fat on metabolite and hormone concentrations of beef cows and their suckling calves. Journal of Animal Science 84: 1038-47.

Prasad S and Tomar O S. 1994. 'Studies on body condition scoring and feeding management in relation to production performance of crossbred dairy cattle'. PhD Thesis, NDRI (Deemed University), Karnal, Haryana, India.

Roche J R, Lee J M, Macdonald K A and Berry D P. 2007. Relationships between body condition score, body weight and milk production variables in pasture-based dairy cows. Journal of Dairy Science 90: 3802-15.

Schroder U J and Staufenbiel R. 2006. Methods to determine body fat reserves in the dairy cow with special regard to ultrasonographic measurement of back fat thickness. Journal of Dairy Science 89: 1-14.

Snedecor G W and Cochran W G. 1994. Statistical Methods. ( $8^{\text {th }}$ edn). Affiliated East-West Press and Iowa State University Press.

Talokar A J, Mandal A, Singh L A, Behera R, Karunakaran M, Ghoshm K and Bhakat C. 2018. Genetic analysis of non-return and conception rate of Jersey crossbred cattle. Indian Journal of Animal Sciences 88(4): 431-33. 